\title{
New records of agaricoid fungi (Basidiomycota) from Paraíba, Brazil
}

\author{
Altielys Casale Magnago ${ }^{1 *}$ \\ Ariadne Nóbrega Marinho Furtado ${ }^{1}$ \\ Salomé Urrea-Valencia ${ }^{1}$ \\ Anne Falcão Freitas ${ }^{2}$ \\ Maria Alice Neves ${ }^{1}$
${ }^{1}$ Universidade Federal de Santa Catarina, Campus Universitário Reitor João David Ferreira Lima Centro de Ciências Biológicas, Departamento de Botânica, Trindade CEP 88040-960, Florianópolis - SC, Brasil
${ }^{2}$ Universidade Federal da Paraíba, Centro de Ciências Biológicas, PRODEMA
João Pessoa - PB, Brasil
* Autor para correspondência altielys@gmail.com

Submetido em 15/07/2014

Aceito para publicação em 07/07/2015

\section{Resumo}

Novos registros de fungos agaricoides (Basidiomycota) na Paraíba, Brasil. $\mathrm{O}$ artigo apresenta uma lista de dezoito espécies de fungos agaricoides coletadas na Mata Atlântica paraibana. Hygrocybe subcaespitosa e Marasmius similis são novos registros para o Brasil. Dezesseis espécies são novos registros para a Paraíba.

Palavras-chave: Agaricales; Cogumelos; Mata Atlântica; Nordeste

\section{Abstract}

This work presents a list of eighteen species of agaricoid fungi collected in the Atlantic Forest in the state of Paraíba. Hygrocybe subcaespitosa and Marasmius similis are new records for Brazil. Sixteen species are new records for Paraíba.

Key words: Agaricales; Atlantic Forest; Mushrooms; Northeastern

\section{Introduction}

Agaricoid fungi are traditionally known for their mushrooms and are mostly included in Agaricales sensu lato (SINGER, 1986). Modern systematic studies including Agaricales have radically modified the interpretations of the evolution and classification of lamellar mushrooms and their allied groups (HIBBETT et al., 1997; MONCALVO et al., 2002; MATHENY et al., 2006). This has resulted in a larger and morphologically more diverse order that includes 26 families (KIRK et al., 2008). 
Several records of agaricoid fungi have been recently published for northeastern Brazil (GIULIETTI; QUEIROZ, 2006; WARTCHOW; MAIA, 2007; WARTCHOW; CAVALCANTI, 2010; WARTCHOW et al., 2007a; 2007b; 2009; 2011; OLIVEIRA, 2009; ARAÚJO et al., 2011; PINHEIRO et al., 2013). A Guide to the Common Fungi of the Semiarid Region of Brazil (NEVES et al., 2013) and Fungos do Parque Nacional do Catimbau (MAIA, 2015) have revealed a great diversity of macrofungi from the semiarid region; however, very little is known about fungi from the state of Paraíba.

The mosaic vegetation found in Paraíba ranges from Atlantic Forest along the coast to a semiarid region in the interior, and this diversity provides a wide range of ecological niches for fungi. Since European colonization, many areas of northeastern Brazil have been deforested (e.g., for cattle and sugarcane farms), which is threatening the environment in this region (RIBEIRO et al., 2009). The Atlantic Forest once covered ca. 15\% of Brazil, of which $20.37 \%$ in the Northeast Region. However, only $15.58 \%$ of the original forest in the Northeast Region remains (SOS MATA ATLÂNTICA, 2014).
The goals of this work are to present a list of species of agaricoid fungi collected in the Atlantic Forest of Paraíba and to contribute to the knowledge of the tropical mycota.

\section{Material and Methods}

Paraíba is located in the Northeast Region of Brazil (Figure 1). It covers an area of $56,439 \mathrm{~km}^{2}$ and its coast has a humid tropical climate with abundant rainfall. Further away from the coast, beyond the Borborema Plateau, the state has a semiarid climate that is subjected to prolonged droughts (SILVA et al., 2003; LEAL et al., 2005).

Fieldwork was conducted between May 2009 and July 2011, in the following fragments of Atlantic Forest in Paraíba: João Pessoa, at the Universidade Federal da Paraíba (0708'S, 34 $\left.50^{\circ} \mathrm{W}\right)$ and the Jardim Botânico Benjamim Maranhão (07 06'S, 34 $52^{\circ}$ W); Mamanguape, at the Reserva Biológica Guaribas (06 $44^{\circ} \mathrm{S}, 35^{\circ} 9^{\prime} \mathrm{W}$ ); and Cabedelo (06 $59^{\circ} \mathrm{S}, 34^{\circ} 49^{\prime} \mathrm{W}$ ).

FIGURE 1: Map of Paraíba showing the collection localities.

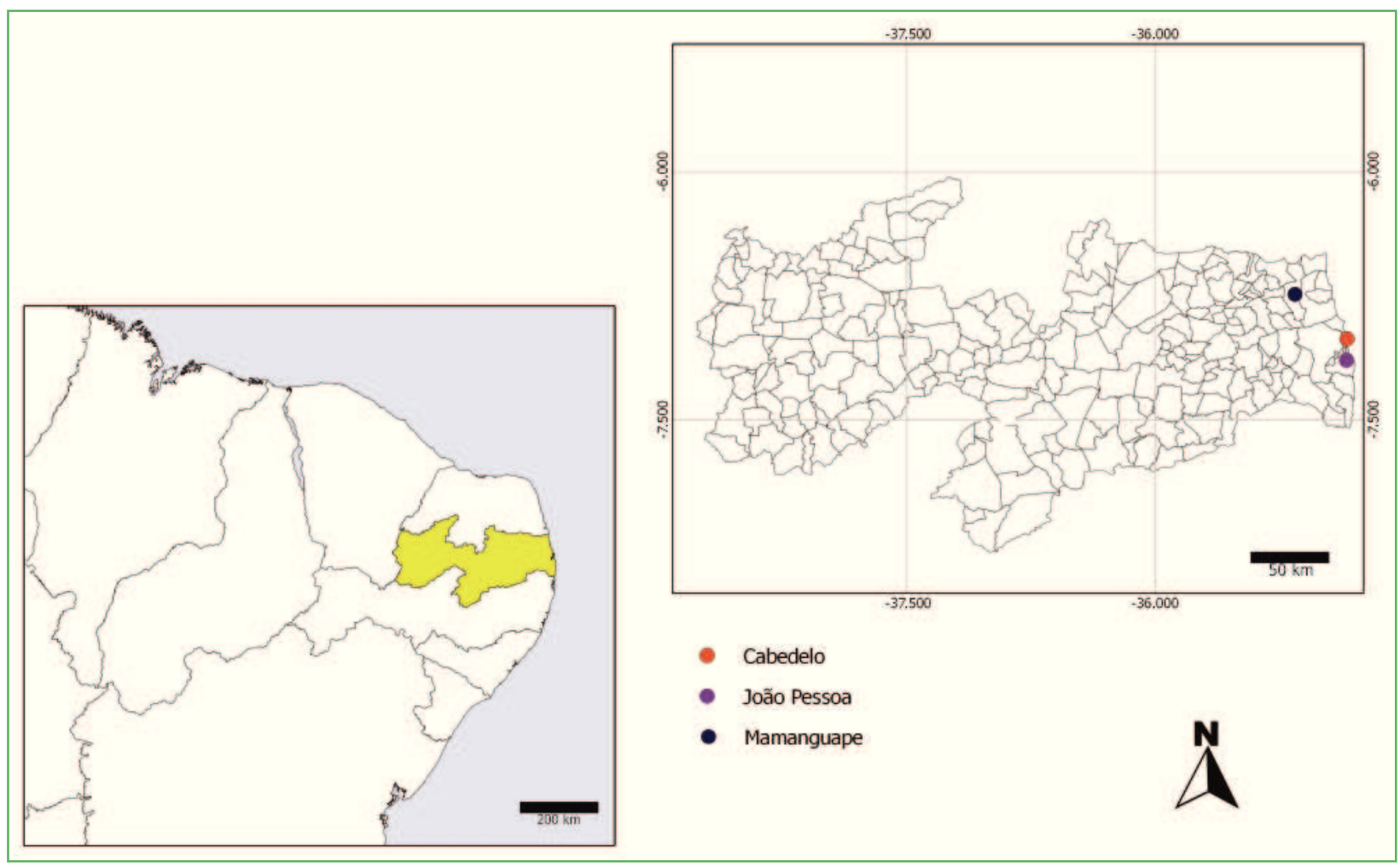


The specimens were studied and preserved following traditional methods used in mycology (MULLER et al., 2004). Micro and macroscopic characters of the basidiomes were described according to Largent et al. (1977). Macromorphological observations were based on fresh basidiomes. Color codes (e.g., OAC635) are based on the Online Auction Color Chart (Kramer 2004). For the microscopic observations, thin sections of dried specimens were rehydrated in $70 \%$ ethanol, followed by $5 \% \mathrm{KOH}$ or Melzer's reagent. For the spore measurements, Qm denotes the mean of length $\times$ width and $\mathrm{n} / \mathrm{s}$ the number of spores measured. The specimens were deposited at JPB (THIERS, continuously updated).

\section{Results}

Eighteen species in 9 genera, distributed in 9 families within Agaricales, were collected. Hygrocybe subcaespitosa and Marasmius similis are new records for Brazil (marked with \# in the list), and sixteen species are new records for the state of Paraíba (marked with $*$ in the list).

Agaricaceae Chevall.

*Leucocoprinus fragilissimus (Berk. \& M.A. Curtis) Pat., Essai taxonomique sur les familles et les genres des Hyménomycètes: 171 (1900) (Figure 3A)

Description and illustrations: Smith and Weber (1982), Rother and Silveira (2009).

Distribution in Brazil: Paraíba (present study), Paraná (MEIJER, 2006), Pernambuco (WARTCHOW et al., 2007b), Rio Grande do Sul (RICK, 1961 [as Lepiota licmophora]; ALBUQUERQUE et al., 2006; ROTHER; SILVEIRA, 2008; 2009), Rondônia (CAPELARI; MAZIERO, 1988), and São Paulo (BONONI et al., 1981).

Specimen examined: BRAZIL, PARAÍBA: João Pessoa, Jardim Botânico Benjamin Maranhão 23 July 2010, A.C. Magnago 254 (JPB50674).

Comments: Leucocoprinus fragilissimus is easily distinguished by its fragile and light yellowish basidiomes. Leucocoprinus magnicystidiosus H.V. Sm.
\& N.S. Weber is a similar species that has a darker colored disc on the pileus surface and much larger and conspicuous cheilocystidia (BRANCO-DIOS, 2003).

Amanitaceae R. Heim ex Pouzar

*Amanita crebresulcata Bas, Persoonia 10 (1): 18 (1978) (Figure 3B)

Description and illustrations: Wartchow and Maia (2007).

Distribution in Brazil: Amazonas (BAS, 1978), Paraíba (present study), Paraná (MEIJER, 2006, as “ $A$. cf. crebresulcata"), Pernambuco (WARTCHOW; MAIA, 2007), and São Paulo (BONONI et al., 1984; GRANDI et al., 1984; PEGLER, 1997).

Specimen examined: BRAZIL, PARAÍBA: João Pessoa, Universidade Federal da Paraíba, 23 June 2010, A.C. Magnago 256 (JPB50676).

Comments: Amanita crebresulcata is similar to A. craseoderma Bas, but the latter has evanescent dark brown warts on the pileus, a friable volva forming a belt at the stipe base, and globose basidiospores. Amanita coacta Bas differs from $A$. crebresulcata mainly by its broader, ellipsoid spores (BAS, 1978; WARTCHOW; MAIA, 2007).

\section{Entolomataceae Kotlaba \& Pouzar}

*Entoloma bloxamii (Berk. \& Broome) Sacc., Sylloge Fungorum 5: 684 (1887) (Figure 3C)

Description and illustrations: Meijer (2008).

Distribution in Brazil: Paraíba (present study), and Paraná (MEIJER, 2008).

Specimen examined: BRAZIL, PARAÍBA: João Pessoa, Universidade Federal da Paraíba, 28 June 2010, A.C. Magnago 245 (JPB50671).

Comments: Entoloma bloxamii presents a bluish gray to violaceous pileus and is similar to $E$. coeruleogracilis G.M. Gates \& Noordel. and E. kermandii G. Gates \& Noordel. Entoloma coeruleogracilis can be distinguished by its small mycenoid basidiomes, and small spores, and E. kermandii has more pronounced angled spores (GATES; NOORDELOOS, 2007). 


\section{Hygrophoraceae Roze}

*Hygrocybe batistae Singer, Atas do Instituto de Micologia da Universidade do Recife 2: 20 (1965) (Figure 3D)

Description and illustrations: Singer (1965), Lodge and Ovrebo (2008).

Distribution in Brazil: Pernambuco (SINGER, 1965), and Paraíba (present study).

Specimen examined: BRAZIL, PARAÍBA: Mamanguape, Reserva Biológica Guaribas, 18 July 2009, J. L. Valões 16 (JPB44297).

Comments: Hygrocybe batistae belongs to section Firmae (Heinemann, 1963) because it has dimorphic basidia and spores in the same basidiome. Two very distinctive characters of $H$. batistae are the presence of coralloid diverticulae and branched pileipellis hyphae. Hygrocybe batistae is very similar to $H$. paraibensis Singer, differing from the later by spore size and the shape and arrangement of the hyphae in the pilleipelis (SINGER, 1965).

*Hygrocybe occidentalis var. scarletina Pegler \& Fiard, Kew Bulletin 32 (2): 311 (1978) (Figure 3E)

Descriptions and illustrations: Pegler and Fiard (1978), Lodge and Pegler (1990).

Distribution in Brazil: Paraíba (present study), and São Paulo (PEGLER, 1997).

Specimens examined: BRAZIL, PARAÍBA: Mamanguape, Reserva Biológica Guaribas, 18 July 2009, A.C. Magnago 80 (JPB44272), 81 (JPB44273), 82 (JPB44274).

Comments: Hygrocybe occidentalis var. scarletina is considered a color variant of $H$. occidentalis var. occidentalis (Dennis) Pegler. Hygrocybe occidentalis var. scarletina is characterized by its glabrous, translucentstriate pileus, which is almost always perforated at the center in mature specimens. The hymenophore is never white and the context is soft-aqueous and hygrophanous (PEGLER; FIARD, 1978).

\#Hygrocybe subcaespitosa (Murrill) Lodge \& Pegler, Mycological Research 94(4): 454 (1990) (Figure 2, 3F)
Pileus $0.5-1.5 \mathrm{~cm}$ diam., convex to applanate, slightly depressed, surface pruinose and reddish (OAC629) in the center, becoming smooth and redorange (OAC691) to light orange (OAC763) towards the margin, hygrophanous, margin translucent-striate when moist. Lamellae adnate to subdecurrent, waxy, whitish to light yellow (OAC814), closely spaced, lamellulae present, of two lengths. Stipe 1.0-3.5 $\times$ 0.1-1.5 cm, central, cylindrical, surface smooth to slightly fibrillose, concolor with pileus, hollow, context whitish, mycelium basal white to cream (OAC816). Spores 8-10 $\times 4-6 \mu \mathrm{m},(\mathrm{Qm}=1.8, \mathrm{n} / \mathrm{s}=20)$, ovoid to oblong ellipsoid, monomorphic, nonamiloid, hyaline, thin-walled, guttules 1 or 2. Basidia 32-50 × 6-13 $\mu \mathrm{m}$, monomorphics, clavate, $2-4$ sterigmate, sterigma 4-6 $\mu \mathrm{m}$ long. Lamellae edge fertile. Cystidia absent. Hymenophoral trama subregular to regular, hyphae 4-11 $\mu \mathrm{m}$ diam. Pileipellis repent with some erect hyphae, hyphae 3-10 $\mu \mathrm{m}$ diam., clamp connections present.

Distribution in Brazil: Paraíba (present study).

FIGURE 2: Microstructures of Hygrocybe subcaespitosa. A-Basidia, B-Basidiospores, C-Pileipellis. Scale bar $=10 \mu \mathrm{m}$.

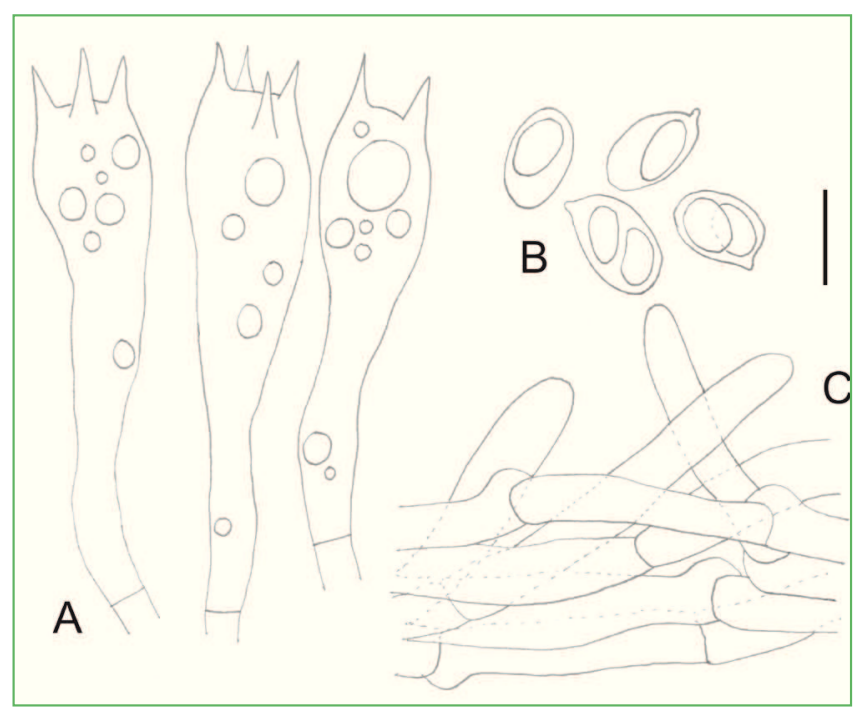

Specimens examined: BRAZIL, PARAÍBA: Mamanguape, Reserva Biológica Guaribas, 18 July 2009, A.C. Magnago 49 (JPB44265), 60 (JPB44266), 72 (JPB44271); 01 August 2009, A.C. Magnago 94 (JPB44275), 98 (JPB44279), 103 (JPB44280), 108 (JPB44283). 
FIGURE 3: (A) Leucocoprinus fragilissimus, (B) Amanita crebresulcata, (C) Entoloma bloxamii, (D) Hygrocybe batistae, (E) Hygrocybe occidentalis var. scarletina, $(\mathrm{F})$ Hygrocybe subcaespitosa. Scale bar $=2.5 \mathrm{~cm}$.
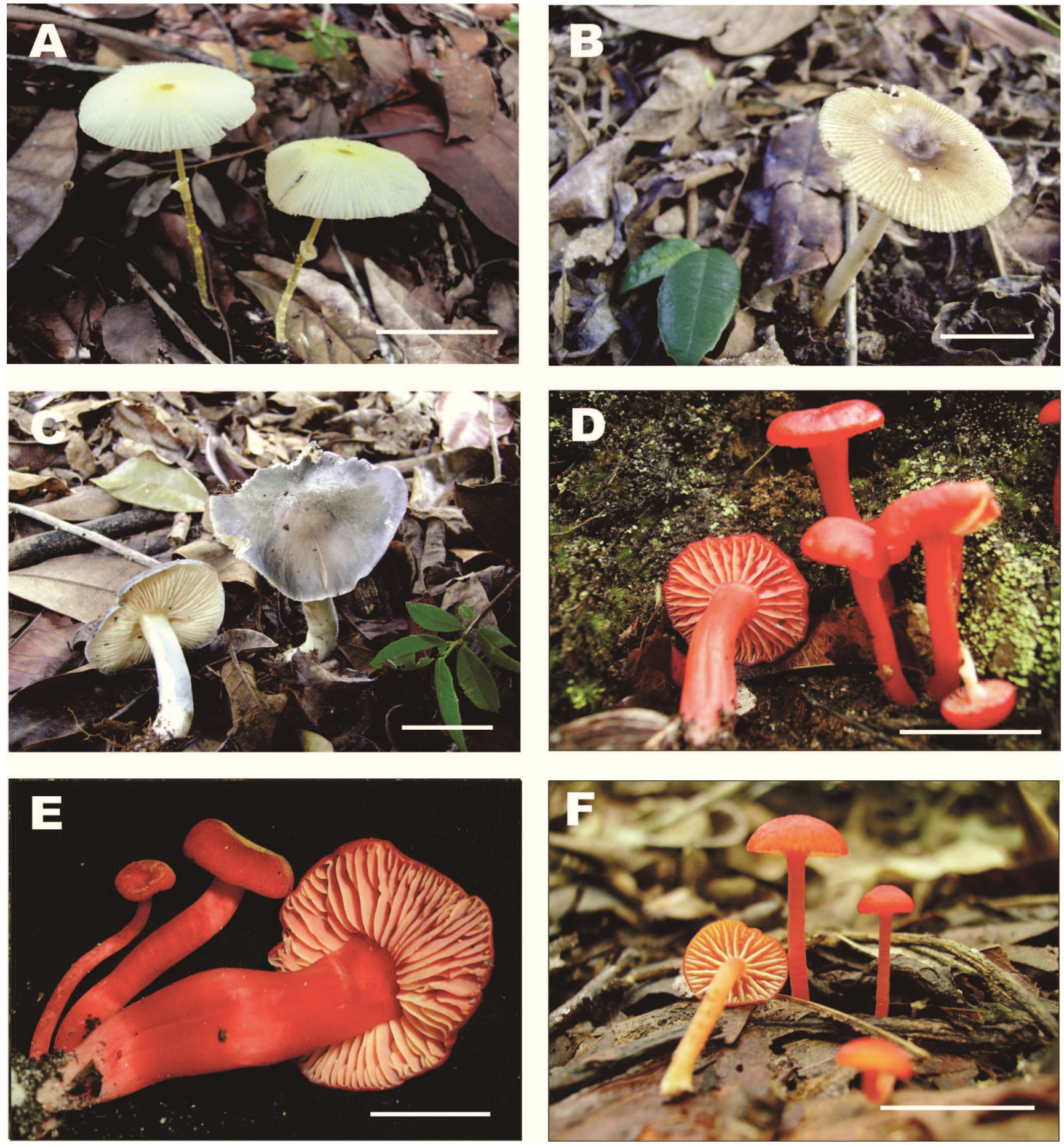
Comments: Hygrocybe subcaespitosa resembles $H$. miniata (Fr.) Kummer; however, the lamellae of $H$. subcaespitosa are usually whitish to pale yellow rather than concolor with a pileus like $H$. miniata. In addition, the hyphae in the hymenophoral trama are consistently narrower in $H$. subcaespitosa (LODGE; PEGLER, 1990).
*Hygrocybe trinitensis (Dennis) Pegler, Kew Bulletin 32 (2): 306 (1978) (Figure 4A)

Descriptions and illustrations: Pegler and Fiard (1978), Cantrell and Lodge (2001).

Distribution in Brazil: Paraíba (present study), and São Paulo (PEGLER, 1997).

FIGURE 4: (A) Hygrocybe trinitensis, (B) Marasmius crinis-equi, (C) Marasmius ferrugineus var. gardineri, (D) Marasmius cf. helvolus, (E) Marasmius leoninus, (F) Marasmius phaeus. Scale bar $=2.5 \mathrm{~cm}$.
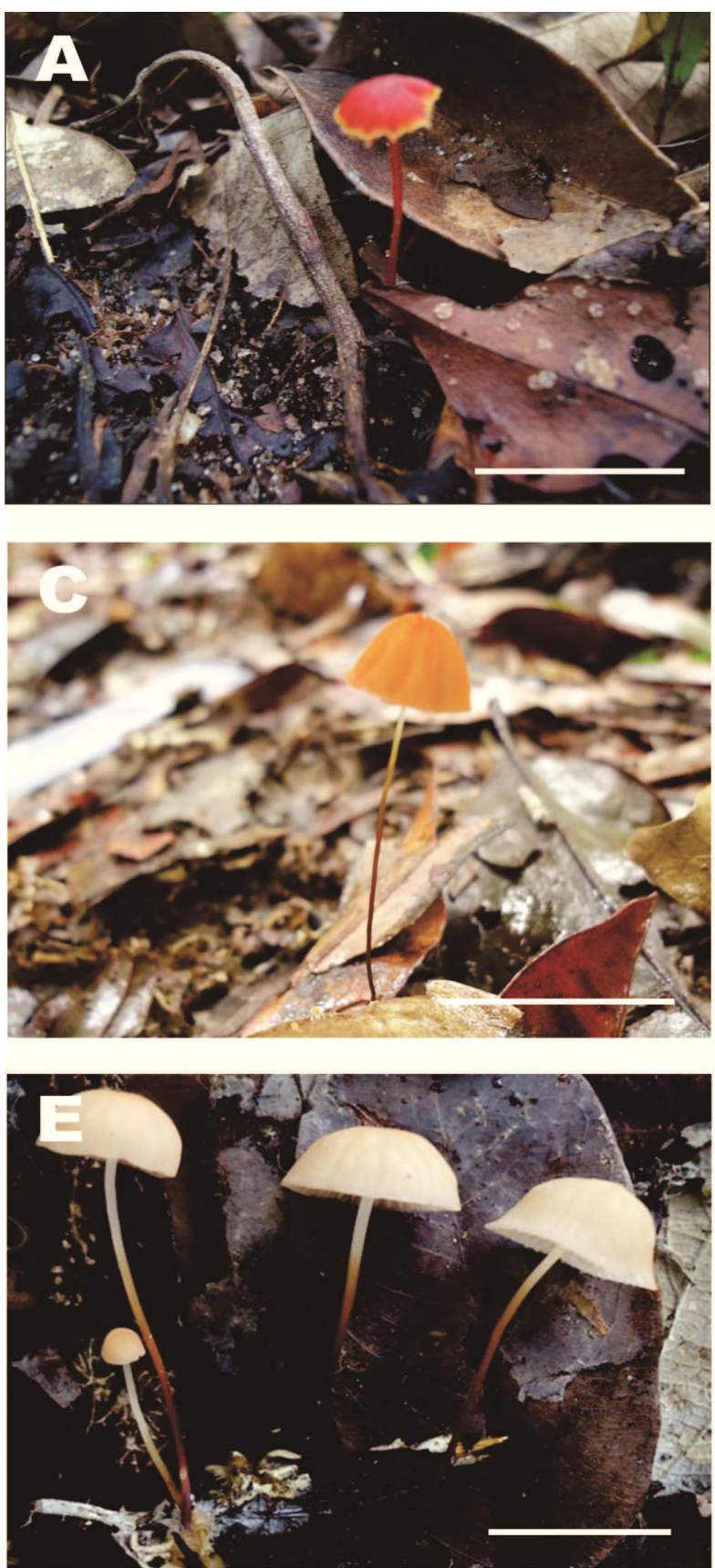
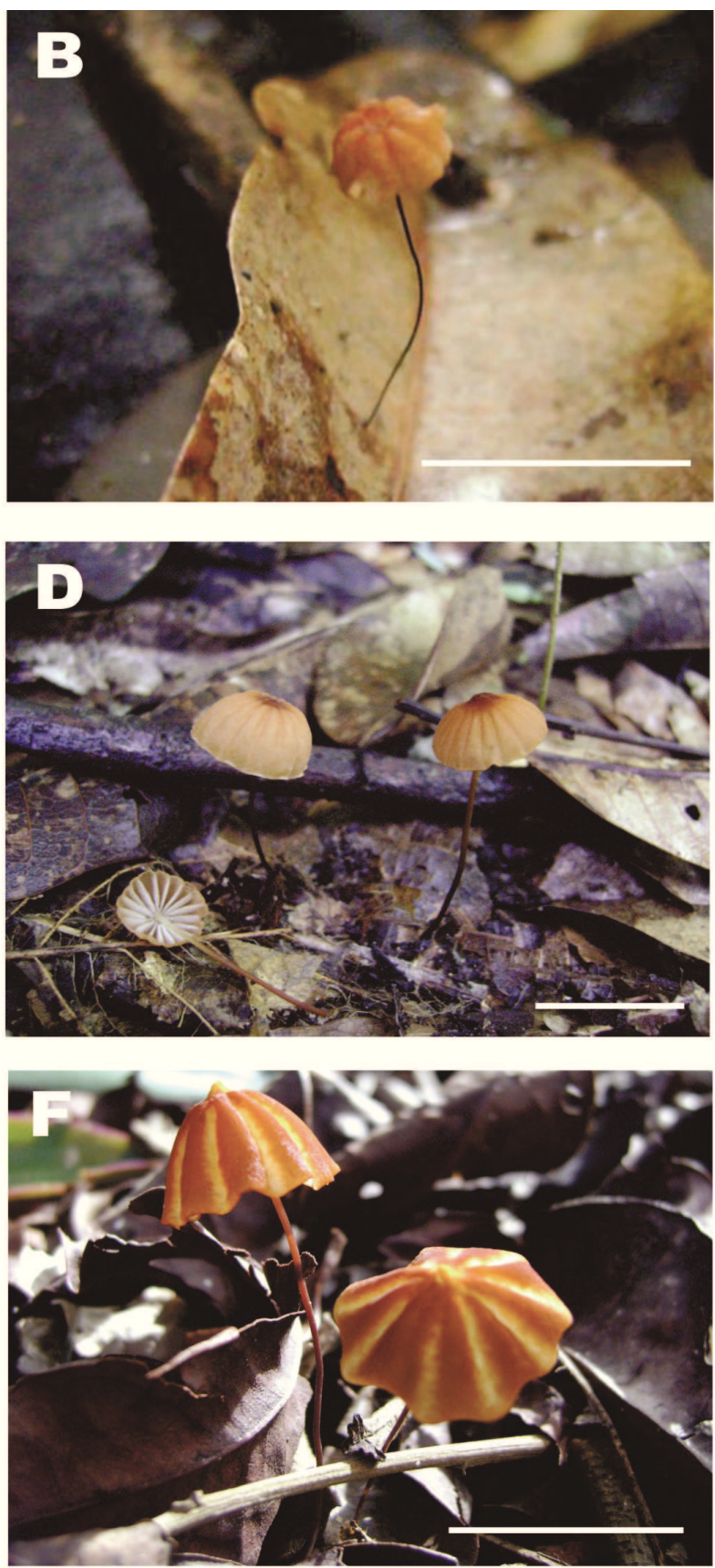
Specimen examined: BRAZIL, PARAÍBA: Mamanguape, Reserva Biológica Guaribas, 01 August 2009, M.T.M. Figueirêdo 33 (JPB44285).

Comments: Hygrocybe trinitensis is minute and bright red. This species lacks cheilocystidia and has a pileus that is cylindric to truncate-parabolic, umbilicate, reaching $10 \mathrm{~mm}$ diam., with a scalloped yellow margin (CANTRELL; LODGE, 2001). Hygrocybe batistae Singer is similar, but has a larger pileus (to $20 \mathrm{~mm}$ diam.) and persistently whitish hymenophore (PEGLER; FIARD, 1978).

\section{Marasmiaceae Rose ex Kuhner}

*Marasmius crinis-equi F. Muell. ex Kalchbr., in Kalchbrenner, Grevillea 8(48):153 (1880) (Figure 4B)

Description and illustrations: Singer (1976).

Distribution in Brazil: Paraíba (present study), Paraná (MEIJER, 2006), and Santa Catarina (KARSTED; STÜRMER, 2008).

Specimens examined: BRAZIL, PARAÍBA: João Pessoa, Jardim Botânico Benjamim Maranhão, 12 June 2010, A.F. Freitas 32 (JPB48125) , 42 (JPB48129); 09 July 2010, A.F. Freitas 96 (JPB48149); 08 April 2011, A.F. Freitas 193 (JPB48186); Universidade Federal da Paraíba, 03 August 2010, A.F. Freitas 137 (JPB48163); 11 March 2011, A.F. Freitas 168 (JPB48125).

Comments: Marasmius crinis-equi belongs to section Marasmius subsection Sicciforme. This species is characterized by the following: brownish orange to rusty pileus with a sulcate surface; lamellae edges that are concolorous with the pileus; and stipe that grows from black rhizomorphs. Marasmius crinis-equi differs from M. crinis-equi var. monocotyledonum Singer by its shorter spores $(7-10 \times 3-4 \mu \mathrm{m}$ in $M$. crinisequi and 7.7-11 $\times 3.5-5.1 \mu \mathrm{m}$ in $M$. crinis-equi var. monocotyledonum).

*Marasmius ferrugineus var. gardneri Singer, Norwegian Journal of Botany 24(2): 223 (1976) (Figure 4C)

Description: Singer (1976).

Distribution in Brazil: Minas Gerais (SINGER, 1976), Paraíba (present study), and Rio de Janeiro (SINGER, 1976).
Specimens examined: BRAZIL, PARAÍBA: João Pessoa: Jardim Botânico Benjamim Maranhão, 23 July 2010,A.F. Freitas 128 (JPB48193); Universidade Federal da Paraíba, 02 July 2010, A.F. Freitas 80 (JPB48142); 29 July 2010, A.F. Freitas 131 (JPB48162); 03 July 2010, A.F. Freitas 141 (JPB48164).

Comments: Marasmius ferrugineus var. gardneri is placed in section Sicci subsection Siccini and is characterized by its convex to campanulate orange pileus, white hymenophore, presence of pleurocystidia, and clavate to fusoid spores $(15-19 \times 3.5-4 \mu \mathrm{m})$. Marasmius persicinus Desjardin \& Horak is similar to Marasmius ferrugineus var. gardneri, but M. persicinus lacks pleurocystidia (DESJARDIN et al., 2000).

*Marasmius helvolus Berk., Hooker's Journal of Botany and Kew Garden Miscellany 8: 136 (1856) (Figure 4D)

Description and illustrations: Singer $(1965,1976)$.

Distribution in Brazil: Amazônia (BERKELEY; CURTIS, 1868; PEGLER, 1988; SACCARDO, 1887; SINGER, 1976), Minas Gerais (ROSA; CAPELARI, 2009), and Paraíba (present study).

Specimens examined: BRAZIL, PARAÍBA: João Pessoa, Jardim Botânico Benjamim Maranhão, 23 July 2010, A.F. Freitas 127 (JPB48159); Universidade Federal da Paraíba, 29 July 2010, A.F. Freitas 130 (JPB48161); 03 August 2010, A.F. Freitas 149 (JPB48170).

Comments: Singer (1976) commented that in $M$. helvolus the cystidia may or may not be present, noting that Brazilian specimens usually have them. Based on the presence of pleurocystidia, Singer included the species in series Haematocephali, but he also included the species in the key to series Leonini (pleurocystidia absent) (SINGER, 1976; DESJARDIN; OVREBO, 2006).

*Marasmius leoninus Berk., Hooker's Journal of Botany and Kew Garden Miscellany 8: 135 (1856) (Figure 4E)

Description and illustrations: Singer $(1965 ; 1976)$, Pegler (1988).

Distribution in Brazil: Amazonas (BERKELEY, 1856; SINGER, 1976), Minas Gerais, Paraná (ROSA; 
CAPELARI, 2009), Paraíba (present study), Rio Grande do Sul (SINGER, 1976), and São Paulo (PEGLER, 1997).

Specimens examined: BRAZIL, PARAÍBA: João Pessoa, Jardim Botânico Benjamim Maranhão, 23 July 2010, A.F. Freitas 126 (JPB48158); Universidade Federal da Paraíba, 18 June 2010, A.F. Freitas 62 (JPB48135); 02 July 2010, A.F. Freitas 84 (JPB48144); 16 July 2010, A.F. Freitas 99 (JPB48150).

Comments: Marasmius leoninus belongs to series Leonini subsection Siccini. This species is characterized by its light to dark orange pileus, fusoid to oblongellipsoid spores, and absence of pleurocystidia. The presence of cheilocystidia can vary in this species (SINGER, 1965). Marasmius bellus Berk. is very similar to $M$. leoninus but differs by its pileus color and spore size (PUCCINELLI; CAPELARI, 2009).

*Marasmius phaeus Berk. \& M.A. Curtis, Botanical Journal of the Linnean Society 10: 298 (1869) (Figure 4F)

Description and illustrations: Singer (1965; 1976).

Distribution in Brazil: Minas Gerais (ROSA; CAPELARI, 2009) and Paraíba (present study).

Specimens examined: BRAZIL, PARAÍBA: João Pessoa, Jardim Botânico Benjamim Maranhão, 23 July 2010, A.F. Freitas 113 (JPB48154); 03 August 2010, A.F. Freitas 144 (JPB48166), 146 (JPB48168); 08 April 2011, A.F. Freitas 192 (JPB48185); Universidade Federal da Paraíba, 04 June 2010, A.F. Freitas 26 (JPB48123); 02 July 2010, A.F. Freitas 83 (JPB48143); 18 April 2010, A.F. Freitas 204 (JPB48188), 205 (JPB48189).

Comments: Marasmius phaeus is characterized by its dark orange to reddish-brown pileus with yellowish radial stripes, distant lamellae, rusty stipe, lanceolate to claviform spores, and absence of pleurocystidia. Marasmius phaeus resembles $M$. tageticolor Berk., but the later has a darker, blood reddish pileus and acicular to subclavate spores (SINGER, 1976).

\#Marasmius similis Berk. \& M.A. Curtis, Hooker's Journal of Botany and Kew Garden Miscellany 1: 100 (1849) (Figure 5, 6A)
Pileus 3-4 mm diam., convex to plane-convex, with an umbo in the center, surface white (OAC909), smooth, dry, sulcate towards margin, membranous. Lamellae free, not collariate, white, 17-20, distant, lamellulae absent. Stipe 10-17 × 0.1-0.3 cm, central, cylindrical, surface smooth, hollow, base dark brown (OAC636), becoming light brown (OAC646) to white at the apex. Basal mycelium strigose, light orange (OAC810). Gregarious on angiosperm leaf litter. Spores 11-14 × 3-4 $\mu \mathrm{m}(\mathrm{Qm}=3.92, \mathrm{n} / \mathrm{s}=20)$, ellipsoid to fusoid, nonamiloids, hyaline, thin-walled. Basidia not observed. Basidioles 18-27 $\times$ 4-7 $\mu \mathrm{m}$, clavate to cilindric, 4-sterigmata. Pleurocystidia absent. Cheilocystidia Siccus-type. Hymenophoral trama interwoven, dextrinoid. Pileipellis hymeniform composed by Siccus-type broom cells, thick walled, pyriform.

Distribution in Brazil: Paraíba (present study).

FIGURE 5: Microstructures of Marasmius similis. A-Basidiospores, B-Basidioles, C-Elements Siccustype of pileipellis. Scale bar $=10 \mu \mathrm{m}$.

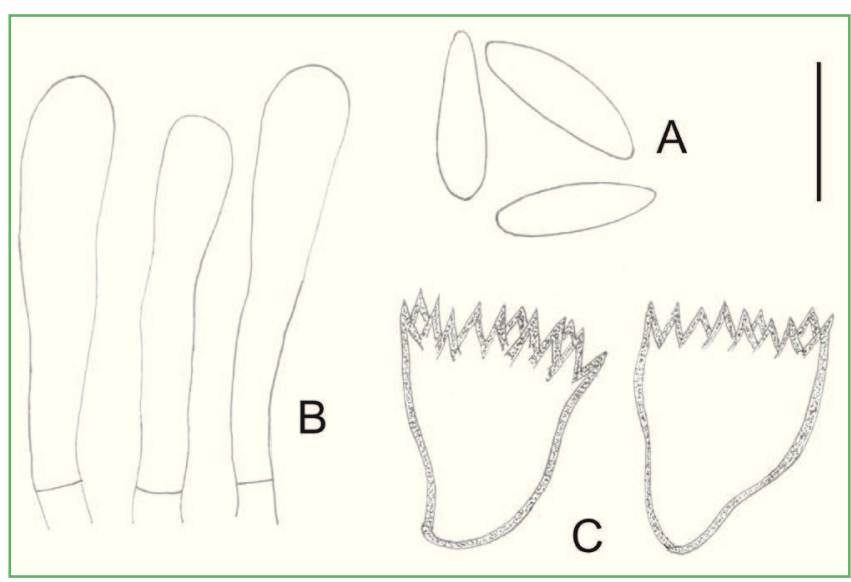

Specimens examined: BRAZIL, PARAÍBA: João Pessoa, Jardim Botânico Benjamim Maranhão, 23 July 2010, A.F. Freitas 112 (JPB48153); 10 August 2010, A.F. Freitas 150 (JPB48171), 153 (JPB48172), 158 (JPB48176).

Comments: The morphology fits well with the description of $M$. similis; however, M. similis is known from only one collection that was found on twigs in a temperate forest in eastern North America and more specimens from this region need to be collected and studied. Marasmius similis belongs to 
section Sicci subsection Siccini. Marasmius bellus Berk. is similar but $M$. similis has a larger cream to light yellowish pileus and fusoid spores. Marasmius cremeus is almost indistinguishable from $M$. similis, even microscopically, but can be distinguished by its white pileus (WANNATHES et al., 2009).

*Marasmius trinitatis Dennis, Transactions of the British Mycological Society 34 (4): 425 (1951) (Figure 6B)
Description: Singer (1965).

Distribution in Brazil: Paraíba (present study), Paraná (MEIJER, 2006), and Rio Grande do Sul (SINGER, 1965).

Specimens examined: BRAZIL, PARAÍBA: João Pessoa, Universidade Federal da Paraíba, 18 June 2010, A.F. Freitas 49 (JPB48131), 56 (JPB48133), 64 (JPB48137).

FIGURE 6: (A) Marasmius similis, (B) Marasmius trinitatis, (C) Dactylosporina steffenii, (D) Coprinellus disseminates, (E) Gymnopilus subtropicus, (F) Leucopaxillus gracillimus. Scale bar $=2.5 \mathrm{~cm}$.
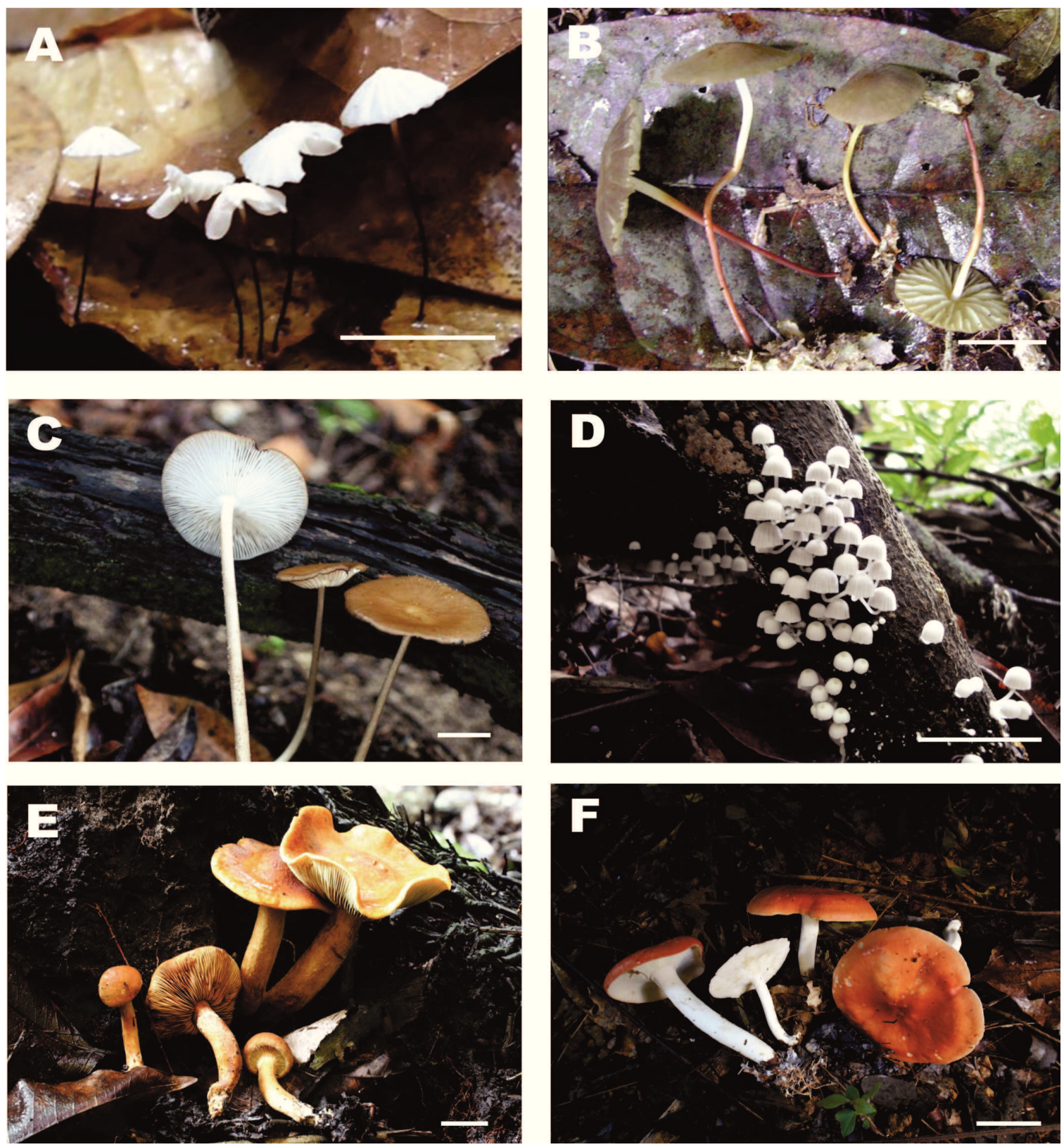
Comments: Marasmius trinitatis is a common species in the Neotropics and is similar to M. makok Wannathes, Desjardin \& S. Lumyongand. Both species have an olive green pileus. Marasmius trinitatis, however, differs by its campanulate-convex pileus, larger number of lamellae, brownish to fulvous stipe, and smaller basidiospores (SINGER, 1976; WANNATHES et al., 2009).

\section{Physalacriaceae Corner}

*Dactylosporina steffenii (Rick) Dörfelt, Feddes Repertorium Specierum Novarum Regni Vegetabilis 96: 237 (1985) (Figure 6C)

Description: Capelari and Gugliotta (2005).

Distribution in Brazil: Minas Gerais, Paraíba (present study), Paraná, Pernambuco, Rio Grande do Sul and São Paulo (CAPELARI; GUGLIOTTA, 2005; WARTCHOW et al., 2010).

Specimens examined: BRAZIL, PARAÍBA: João Pessoa, Universidade Federal da Paraíba, 29 April 2010, A.N.M. Furtado 11 (JPB50651); Jardim Botânico Benjamin Maranhão 12 June 2010, A.C. Magnago 225 (JPB50667).

Comments: Dactylosporina steffenii and D. macracantha (Rick) Dörfelt are closely related species and Singer (1964) points out that the differential character between them is the length of the ornamentations of the spores (1.4-3.5 $\mu \mathrm{m}$ in D. steffenii and 3.5-5.5 $\mu \mathrm{m}$ in D. macracantha). Dactylosporina steffenii also has a slender, longer stipe and larger pileus. Even though both species grow in the tropics, D. steffenii is the only one that grows in the subtropics (SINGER, 1964).

Psathyrellaceae Vilgalys, Moncalvo \& Redhead

*Coprinellus disseminates (Pers.) J.E. Lange, Dansk Botanisk Arkiv 9 (6): 93 (1938) (Figure 6D)

Description and illustrations: Keirle et al. (2004).

Distribution in Brazil: Paraíba (present study), Rio Grande do Sul and São Paulo (PEGLER, 1997).

Specimen examined: BRAZIL, PARAÍBA: João Pessoa, Jardim Botânico Benjamin Maranhão 12 June 2010, A.C. Magnago 230 (JPB50668).
Comments: Coprinellus disseminatus is a very common wood decomposer and its deliquescent pileus leads many taxonomists to identify it as Psathyrella (Fr.) Quél. or Coprinus Pers. However, molecular studies have placed $C$. disseminatus in a well-supported clade with other deliquescent taxa, including Coprinellus micaceus (Bull.) Vilgalys, Hopple \& Jacq. Johnson (HOPPLE; VILGALYS, 1999). Coprinellus disseminatus is commonly confused with Coprinellus curtus (Kalchbr.) Vilgalys, Hopple \& Jacq. Johnson. Both species grow on wood and form large groups of fragile basidiomes. However, C. curtus is brownish red at the center of the pileus and $C$. disseminatus is completely grey.

Strophariaceae Sing. \& Smith

*Gymnopilus subtropicus Hesler, Mycologia Memoirs 3: 41 (1969) (Figure 6E)

Description: Singer and Gómez (1982).

Distribution in Brazil: Paraíba (present study), Paraná and Rio Grande do Sul (MEIJER, 2006).

Specimen examined: BRASIL, PARAÍBA: João Pessoa, Jardim Botânico Benjamin Maranhão 09 July 2010, A.C. Magnago 246 (JPB50672).

Comments: Gymnopilus subtropicus has a yelloworange to rusty color throughout the basidiome and thin fibrils over the pileus. The basidiomes are robust and resemble G. junonius (Fr.) P.D. Orton. However, $G$. junonius has smaller spores with a more persistent, curtain-like veil on the stipe that forms a well-defined ring zone (ARORA, 1986).

\section{Tricholomataceae Roze}

*Leucopaxillus gracillimus Singer \& A.H. Sm., Papers of the Michigan Academy of Sciences 28: 131 (1943) (Figure 6F)

Description and illustrations: Araújo et al. (2011).

Distribution in Brazil: Minas Gerais, Paraná, Pernambuco, Rio Grande do Sul, Santa Catarina (ARAÚJO et al., 2011), and Paraíba (present study).

Specimen examined: BRAZIL, PARAÍBA: João Pessoa, Universidade Federal da Paraíba, 09 March 2010, A.C. Magnago 69 (JPB50662). 
Comments: Leucopaxillus gracillimus is easily recognized by its dark, orange pileus and whitish hymenophore (PEGLER, 1983). Leucopaxillus brasiliensis (Rick) Singer \& A.H. Sm. has similar characteristics but can be distinguished by its reddishbrown to brownish-purple pileus, yellowish-orange stem and yellowish hymenophore.

\section{Acknowledgments}

The authors thank the collecting sites for the permits and the support during fieldwork. We also thank Nathan Smith for reviewing the English and Sérgio Campestrini for helping with the maps. ACM thanks FAPESB for the ITI-A fellowship and ANMF thanks the Conselho Nacional de Desenvolvimento Científico e Tecnológico (CNPq) for the PIBIC fellowship.

\section{References}

ARORA D. Mushrooms demystified: a comprehensive guide to the fleshy fungi. 2. ed. New York: Ten Speed Press, 1986. 1020 p.

ALBURQUEQUE, P. M. Fungos Agaricales em trechos de mata atlântica da Reserva Biológica do Tinguá, Nova Iguaçú, Rio de Janeiro, Brasil. 2006. 288 f. Dissertação (Mestrado em Botânica) - Instituto de Pesquisas do Jardim Botânico do Rio de Janeiro, Escola Nacional de Botânica Tropical, Rio de Janeiro. 2006.

ARAÚJO, J. P. M.; COIMBRA, V. R. M.; WARTCHOW, F. Leucopaxillus gracillimus (Tricholomataceae, Basidiomycota): new record from Northeast Brazil and notes on its distribution. Kurtziana, Córdoba, v. 36, n. 2, p. 5-9, 2011.

BAS, C. Studies in Amanita - I. Some species from Amazonia. Persoonia, Leiden, v. 10, n. 1, p. 1-22, 1978.

BERKELEY, M. J. Decades of fungi LI-LIV: Rio Negro Fungi. Hooker's Journal of Botany \& Kew Miscellaneous, London, v. 8, p. 129-144, 1856.

BERKELEY, M. J.; CURTIS, M. A. Fungi Cubenses (Hymenomycetes). Journal of the Linnean Society Botany, London, v. 46, n. 10, p. 321-341, 1868.

BONONI, V. L.; MUCCI, E. S. F.; YOKOMIZO, N. K. S.; GUZMÁN, G. Agaricales (Basidiomycetes) do Parque Estadual de Campus do Jordão, SP, Brasil. Rickia, São Paulo, v. 11, p. 85-89, 1984.

BONONI, V. L. R.; TRUFEM, S. F. B.; GRANDI, R. A. P. Fungos macroscópicos do Parque Estadual das Fontes do Ipiranga. Rickia, São Paulo, v. 9, p. 37-53, 1981.

BRANCO-DIOS, J. B. Estudios sobre el género Leucocoprinus Pat. En la península ibérica (II). Leucocoprinus castroi sp. nov. Revista Catalana de Micologia, Barcelona, v. 25, p. 41-47, 2003.

CANTRELL, S. A.; LODGE, J. Hygrophoraceae (Agaricales) of the Greater Antilles: Hygrocybe subgenus Pseudohygrocybe section Firmae. Mycological Research, Manchester, v. 105, n. 2, p. 215-224, 2001.

CAPELARI, M.; GUGLIOTTA, A. M. Dactylosporina e Oudemansiella (Tricholomataceae, Oudemansiellinae) do Parque Estadual das Fontes do Ipiranga (PEFI), São Paulo, SP. Hoehnea, São Paulo, v. 32, n. 3, p. 381-387, 2005.

CAPELARI, M.; MAZIERO, R. Fungos macroscópicos do estado de Rondônia região dos Rios Jaru e Ji-Paraná. Hoehnea, São Paulo, v. 15 , p. 28-36, 1988.

DESJARDIN, D. E.; OVREBO, C. L. New species and new records of Marasmius from Panamá. Fungal Diversity, Chiang Mai, v. 21, p. 19-39, 2006.

DESJARDIN, D. E.; RETNOWATI, A.; HORAK, E. Agaricales of Indonesia II. A preliminary monograph of Marasmius from Java and Bali. Sydowia, Vienna, v. 52, p. 92-193, 2000.

GATES, G. M.; NOORDELOOS, M. Preliminary studies in the genus Entoloma in Tasmania. Persoonia, Leiden, v. 19, n. 2, p. 157-226, 2007.

GIULIETTI, A. M.; QUEIROZ, L. P. O Instituto do Milênio do Semi-árido (IMSEAR), Brasil. In. GUSMÃO, L. F. P.; MAIA, L. C. (Ed.). Diversidade e caracterização dos fungos do Semi-Árido Brasileiro. Vol. 2. Recife: Associação Plantas do Nordeste, 2006. p. 1-11.

GRANDI, R. A. P.; GUZMÁN, G.; BONONI, V. L. Adições a Agaricales (Basidiomycetes) do Parque Estadual das Fontes do Ipiranga, São Paulo, SP, Brasil. Rickia, São Paulo, v. 11, p. 27-33, 1984.

GUZMÁN-DÁVALOS, L.; OVREBO, C. L. Some species of Gymnopilus from Costa Rica and Panama. Mycologia, Standford, v. 93, n. 2, p. 398-404, 2001.

HESLER, L.R. North American Species of Gymnopilus. Knoxville, Tennessee: Lubrecht \& Cramer Ltd. Mycologia Memoir Series, v. 3, p. 41-42, 1969.

HIBBETT, D. S.; PINE, E. M.; LANGER, E.; LANGER, G.; DONOGHUE, M. J. Evolution of gilled mushrooms and puffballs inferred from ribosomal DNA sequences. Proceedings of the National Academy of Science, Washington, v. 94, n. 22, p. $12002-$ 12006, 1997.

HOPPLE, J. S. JR.; VILGALYS, R. Phylogenetic relationships in the mushroom genus Coprinus and the dark-spored allies based on sequence data from the nuclear gene coding for the large ribosomal subunit RNA: Divergent domains, Outgroups, and Monophyly. Molecular Phylogenetics and Evolution, New York, v. 13, p. 1-19, 1999.

KARSTEDT, F.; STÜRMER, S. L. Agaricales em áreas de Floresta Ombrófila Densa e plantações de Pinus no estado de Santa Catarina, Brasil. Acta Botanica Brasilica, Feira de Santana, v. 22, n. 4, p. 1036-1043, 2008.

KEIRLE, M. R.; HEMMES, D. E.; DESJARDIN, D. E. Agaricales of the Hawaiian Islands. 8. Agaricaceae: Coprinus and Podaxis; Psathyrellaceae: Coprinopsis, Coprinellus and Parasola. Fungal Diversity, Chiang Mai, v. 15, p. 33-124, 2004.

KIRK, P. M.; CANNON, P. F.; DAVID, J. C.; STALPERS, J. A. Ainsworth and Bisby's dictionary of the fungi. 9. ed. Cambridge: International University Press, 2008. 665 p. 
KRAMER, L. A. The Online Auction Color Chart. Online Auction Color Chart Company, Stanford. 2004. 12 p.

LARGENT, D. L.; JOHNSON, D.; WATLING, R. How to identify mushrooms to Genus III: microscopic features. 3. ed. Eureka: Mad River Press, 1977. 148 p.

LEAL, I. R.; TABARELLI, M.; SILVA, J. M. C. Ecologia e conservação da caatinga. 2 . ed. Recife: Editora Universitária da Universidade Federal de Pernambuco, 2005. 822 p.

LODGE, D. J.; OVREBO, C. L. First records of Hygrophoraceae from Panama including a new species of Camarophyllus and a new veiled species in Hygrocybe section Firmae. Fungal Diversity, Chiang Mai, v. 32, p. 69-80, 2008.

LODGE, D. J.; PEGLER, D. N. Hygrophoraceae of the Luquillo Mountains of Puerto Rico. Mycological Research, Cambridge, v. 94, n. 4, p. 443-456, 1990.

MEIJER, A. A. R. Preliminary list of Macromycetes from the Brazilian state of Paraná. Boletim do Museu Botânico Municipal, Curitiba, v. 68, p. 1-58, 2006.

MEIJER, A. A. R. Macrofungos notáveis das Florestas de Pinheiro-do-Paraná. Colombo: Embrapa Florestas, 2008. 431 p.

MAIA, L. C. Fungos do Parque Nacional do Catimbau (recurso eletrônico). Recife: Editora UFPE. Disponível em: <http://inct. florabrasil.net/en/fungos-parque-nacional-do-catimbau/ $>$. Acesso em: 12 jan. 2015.

MATHENY, P. B.; CURTIS, J. M.; HOFSTETTER, V.; AIME, M. C.; MONCALVO, J. M.; GE, Z. W.; SLOT, J. C.; AMMIRATI, J. F.; BARONI, T. J.; BOUGHER, N. L.; HUGHES, K. W.; LODGE, D. J.; KERRIGAN, R. W.; SEIDL, M. T.; AANEN, D. K.; DENITIS, M.; DANIELE, G. M.; DESJARDIN, D. E.; KROPP, B. R.; NORVELL, L. L.; PARKER, A.; VELLINGA, E. C.; VILGALYS, R.; HIBBETT, D. S. Major clades of Agaricales: a multilocus phylogenetic overview. Mycologia, Stanford, v. 98, p. 982-995, 2006.

MONCALVO, J. M.; VILGALYS, R.; REDHEAD, S. A.; JOHNSON, J. E.; JAMES, T. Y.; CATHERINE AIME, M.; HOFSTETTER, V.; VERDUIN, S. J.; LARSSON, E.; BARONI, T. J.; GREG THORN, R.; JACOBSSON, S.; CLÉMENÇON, H.; MILLER, O. K. One hundred and seventeen clades of euagarics. Molecular Phylogenetics an Evolution, Detroit, v. 23, p. 357-400, 2002.

MULLER, G. M.; BILLS, G. F.; FOSTER, M. S. Biodiversity of Fungi, inventory and monitoring methods. Watham: Elsevier Academic Press, 2004. 777 p.

NEVES, M. A.; BASEIA, I. G.; DRECHSLER-SANTOS, E. R.; GÓES-NETO, A. Guide to the common Fungi of the Semiarid Region of Brazil. 1 ed. Florianópolis: TECC Editora, 2013. 142 p. OLIVEIRA, J. J. S. O gênero Marasmius (Marasmiaceae, Basidiomycota) no Parque Estadual das Dunas do Natal, Natal, RN, Brasil. Monografia (Graduação em Ciências Biológicas) Universidade Federal do Rio Grande do Norte, Natal. 2009.

PINHEIRO, F. G. B.; SÁ, M. C. A.; WARTCHOW, F. Hydropus griseolazulinus, a striking new species from Paraíba, Brazil. Mycosphere, Chiang Rai, v. 4, n. 2, p. 207-214, 2013.

PEGLER, D. N. Agaric flora of Lesser Antilles. Kew Bulletin Additional Series IX. 1983. 406 p.
PEGLER, D. N. Agaricales of Brazil described by M. J. Berkeley. Kew Bulletin, Kew, v. 43, n. 3, p. 453-473, 1988.

PEGLER, D. N. The agarics of São Paulo. An account of the Agaricoid Fungi (Holobasidiomycetes) of São Paulo State, Brazil. London: Royal Botanical Gardens, 1997. 68 p.

PEGLER, D. N.; FIARD, J. P. Hygrocybe sect. Firmae (Agaricales) in tropical America. Kew Bulletin, v. 32, n. 2, p. 297-312, 1978.

PUCCINELLI, C.; CAPELARI, M. Marasmius (Basidiomycota - Marasmiaceae) do Parque Estadual das Fontes do Ipiranga, São Paulo, SP, Brasil: seção Sicci. Hoehnea, São Paulo, v. 36, n. 4, p. 637-655, 2009.

RIBEIRO, M. C.; METZGERA, J. P.; MARTENSENA, A. C.; PONZONIB, F. J.; HIROTAC, M. M. The Brazilian Atlantic Forest: how much is left, and how is the remaining forest distributed? Implications for conservation. Biological Conservation, Boston, v. 142, n. 6, p. 1141-1153, 2009

RICK, J. Basidiomycetes eubasidii in Rio Grande do Sul - Brasilia. 5. Agaricaceae. Iheringia, Série Botânica, Porto Alegre, v. 8, p. 296-450, 1961.

ROSA, L. H.; CAPELARI, M. Agaricales fungi from Atlantic Rain Forest fragments in Minas Gerais, Brazil. Brazilian Journal of Microbiology, São Paulo, v. 40, p. 846-851, 2009.

ROTHER, M.; SILVEIRA, R. M. B. Família Agaricaceae (Agaricales, Basidiomycota) no Parque Estadual de Itapuã, Viamão, Rio Grande do Sul, Brasil. Revista Brasileira de Biociências, Porto Alegre, v. 6, n. 3, p. 259-268, 2008.

ROTHER, M.; SILVEIRA, R. M. B. Leucocoprinus Pat. (Agaricaceae, Basidiomycota) no Parque Estadual de Itapuã, Viamão, RS, Brasil. Acta Botanica Brasilica, Feira de Santana, v. 23, n. 3, p. 720-728, 2009.

SACCARDO, P. A. Sylloge fungorum omnium hucusque cognitorum. V. Patavii (Typis Seminarii), 1887. 1146 p.

SILVA, J. M. C.; TABARELLI, M.; FONSECA, M. T.; LINS, L. V. Biodiversidade da caatinga: áreas e ações prioritárias para a conservação. Brasília: Ministério do Meio Ambiente, Universidade Federal de Pernambuco, 2003. 382 p.

SINGER, R. Oudemansiellinae, Macrocystidiinae, Pseudohiatulinae in South America:

monographs of South American Basidiomycetes, especially those of the east slope of the Andes and Brazil. VIII. Darwiniana, v. 13, p. 145-190, 1964.

SINGER, R. Monographic studies in South American Basidiomycetes, especially those of the east slope of the Andes and Brazil 2. The genus Marasmius in South America. Sydowia, Vienna, v. 18, p. 106-358, 1965.

SINGER, R. Marasmieae (Basidiomycetes - Tricholomataceae). Flora Neotropica, New York, v. 17, p. 1-347, 1976.

SINGER, R. The Agaricales in modern taxonomy. 4. ed. Koenigstein, Germany: Koeltz Scientific Books, 1986. 981 p.

SINGER, R.; GOMÉZ, L. D. Basidiomycetes of Costa Rica. I. Brenesia, San José, v. 19/20, p. 31-47, 1982.

SMITH, H. V.; WEBER, N. S. Selected species of Leucocoprinus from Southeastern United States. Contributions from the University of Michigan Herbarium, Michigan, v. 15, p. 297-309, 1982. 
SOS MATA ATLÂNTICA. Mata Atlântica. 2014. Disponível em: <http:/www.sosma.org.br/wp-content/uploads/2014/05/atlas_ 2012-2013_relatorio_tecnico_20141.pdf>. Acesso: 19 dez. 2014.

THIERS, B. Index Herbariorum: A global directory of public herbaria and associated staff. New York Botanical Garden's Virtual Herbarium. (continuously updated) Disponível em: $<$ http:// sweetgum.nybg.org/ih/>. Acesso em: 22 maio 2013.

WANNATHES, N.; DESJARDIN, D. E.; HYDE, K. D.; PERRY, B. A.; LUMYONG, S. A monograph of Marasmius (Basidiomycota) from Northern Thailand based on morphological and molecular (ITS sequences) data. Fungal Diversity, Chiang Mai, v. 37, p. 209306, 2008.

WARTCHOW, F.; CARVALHO, A. S.; SOUSA, M. C. A.; CORTEZ, V. G. Some coprophilous Psilocybe (Strophariaceae) from Pernambuco State, Northeast Brazil. Sitientibus Série Ciências Biologicas, Feira de Santana, v. 7, n. 2, p. 150-153, 2007a.

WARTCHOW, F.; CAVALCANTI, M. A. Q. Lactarius rupestris - new species from the Brazilian semi-arid region. Mycotaxon, Ithaca, v. 112, p. 55-63, 2010.
WARTCHOW, F.; MAIA, L. C. The Neotropical Amanita crebresulcata Bas: new citation from Northeast Brazil. Hoehnea, São Paulo, v. 34, n. 2, p. 131-134, 2007.

WARTCHOW, F.; MAIA, L. C.; CAVALCANTI, M. A. Q. New records of Agaricales from Atlantic Forest fragments of Pernambuco, Northeast Brazil. Mycotaxon, Ithaca, v. 118, p. $137-$ 146, 2011.

WARTCHOW, F.; PUTZKE, J.; CAVALCANTI, M. A. Q. Agaricaceae Fr. (Agaricales, Basidiomycota) from areas of Atlantic forest in Pernambuco, Brazil. Acta Botanica Brasilica, Feira de Santana, v. 22, n. 1, p. 287-299, 2007 b.

WARTCHOW, F.; TULLOSS, R. E.; CAVALCANTI, M. A. Q. Amanita lippiae: a new species from the semi-arid caatinga region of Brazil. Mycologia, Stanford, v. 101, n. 6, p. 864-870, 2009.

WARTCHOW, F.; PEREIRA, J.; DRECHSLER-SANTOS, E.R.; GOMES-SILVA, A.C.; TIAGO, P.V.; PUTZKE, J.; CAVALCANTI, M. A. Q. Two Oudemansiella species with echinulate basidiospores from South America with $O$. macracantha lectotypified. Mycotaxon, Ithaca, v. 113, p. 119-127, 2010. 